\title{
Morpho-anatomy of Solanum pseudocapsicum
}

\section{Gaurav V. Sanghvi, Rina D. Koyani, Vidya S. Patil, Kishore S. Rajput*}

Department of Botany, Faculty of Science, The Maharaja Sayajirao University of Baroda, India.
Revista Brasileira de Farmacognosia Brazilian Journal of Pharmacognosy 21(1): 11-15, Jan./Feb. 2011

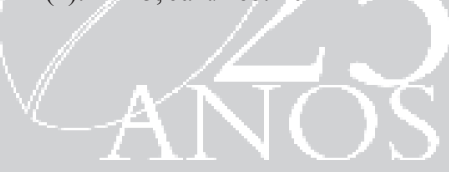

Article

Received 26 Sep 2009

Accepted 5 Aug 2010

Available online 25 Feb 2011

Keywords:

Solanum pseudocapsicum

Solanaceae morpho-anatomy

ISSN $0102-695 \mathrm{X}$ doi: 10.1590/S0102-695X2011005000026

\section{Introduction}

There has been increasing incidence of microbial infection in recent years, largely due to an increase in pathogenesis and emergence of resistant strains. Despite the increasing production of new antimicrobial agents by pharmacological industries over the last three decades, resistance to these drugs by microorganisms is still on the rise. Other factors like low drug potency, poor solubility of drugs, toxicity and also increase of undesirable situation like certain side effects of antibiotics and uncommon infections cause a serious medical problem (Marchese et al., 2001; Poole, 2001). One approach is to screen new, inexpensive and effective drugs from other sources, including plants, for possible antimicrobial properties (Dayang et al., 2005). The use of plant extracts and phytochemicals, both with known antimicrobial properties, can be of great significance in therapeutic treatments (Gislene et al., 2000). The family Solanaceae and genus Solanum, which is one of the plant sources is known to possess antimicrobial constituents.

Solanum pseudocapsicum L., Solanaceae, is profusely branched, compact subshrubs. Stem and branches glabourous terete. Leaves are narrowly elliptic and tapering at both ends, margin undulates. Flower axillary, solitary or 4-22 in clusters. Berries globose, green changing yellow to red at maturity. At maturity colour of berries are attractive, hence it is cultivated as an indoor ornamental. Number of seeds ranges from 50 to 100 , while berries could be as many as 100 per plant (Bassett \& Mundro, 1985).
It is a poisonous plant used in traditional medicine for the treatment of acute abdominal pain (Boericke, 1927), in the treatment of boils and gonorrhea and as tonic for men (Batten \& Bokelmann, 1966). It contains solanocapsine and other alkaloids that are reported to be fatal to man and animals (Parisi \& Francia, 2000). Phytomedical investigations have revealed that the plant possesses antiviral, cytotoxic, hepatoprotective, and antitumor properties (Shrishailappa et al., 2003; Vijayan et al., 2003).

Despite toxicological and volatile components from aerial parts as well as from roots have been documented, there is no information about morphoanatomical features of $S$. pseudocapsicum. It is therefore, necessary to document the morpho-taxonomic characters to avoid the falsification and adulteration of the drug.

\section{Materials and Methods}

\section{Plant material collection}

Aerial and underground parts along with young fruits of Solanum pseudocapsicum L., Solanaceae, was collected from the plants growing in the university campus and from the botanical garden of the M.S. University of Baroda, Vadodara during month of June-July and in December 2008. Collection was done from the naturally growing plants on the slopes of the Buki Nala and the specimens were pressed by routine method of herbarium preparation and submitted to the BARO herbarium of The Maharaja Sayajirao University of Baroda, Vadodara, 
Acc. No.: KSR 13, 48 and 73. Collected plant is new report to the Gujarat State (Rajput \& Raole, 2009) and its identity was verified by Prof. S. R. Yadav, Department of Botany, Shivaji University, Kolhapur (MS), India.

\section{Microtomy}

Suitably trimmed samples of stem, root, leaves and unripe fruits were fixed in FAA (Berlyn \& Miksche, 1976). After $24 \mathrm{~h}$ they were transferred $70 \%$ alcohol and dehydrated with tertiary butyl alcohol series $(30 \%$, $50 \%, 70 \%, 90 \%$ followed by $3 \times 100 \%$ pure TBA) and processed by routine method of paraffin embedding. Thick samples were also sectioned on a sliding microtome. Transverse, radial and tangential longitudinal sections of 12-15 $\mu \mathrm{m}$ thickness were obtained with rotary and sliding microtome and stained with safranin fast green combination (Johansen, 1940). Some of the sections were also stained with iodine/potassium iodide to study the morphology and depositions of starch.

To obtain the length and width of vessel elements, fibriform vessel elements and xylem fibres, small pieces of xylem adjacent to the cambium ring were macerated with Jeffrey's solution (Berlyn \& Miksche, 1976) at 55 to 60 ${ }^{\circ} \mathrm{C}$ for 24-36 h, and stained with safranin to study general morphology and dimensional details. Length and width of the sieve tube elements and fibre nuclei were measured directly from the tangential longitudinal sections. One hundred measurements were chosen randomly to obtain mean and standard deviation for each cell type. Important results were microphotographed with Leica DM 2000 trinocular research microscope.

\section{Results and Discussion}

Solanum pseudocapsicum L., is a perennial, much branched, compact sub-shrub reaching 2 to 4 feet in height. Stem erect, terete, cylindrical, greenish when young and pale ash coloured at maturity. Leaves simple, mostly alternate, narrowly elliptic, tapering at both ends, margin undulate. Lamina 100 to $180 \mathrm{~mm}$ long and 43 to $67 \mathrm{~mm}$ wide, acute, acuminate, glabrous, minutely hairy beneath. Flowers axillary, solitary or 4-22 in clusters, small, pedicellate, pedicel 10 to $12 \mathrm{~mm}$, smooth, hairy when young. Berries globose, dark green when young and yellow to orange at maturity, around 10 to $13 \mathrm{~mm}$ in diameter.

\section{Microscopy}

In transverse view cells of leaf epidermis were barrel shaped with slightly anticlinal walls and possessed
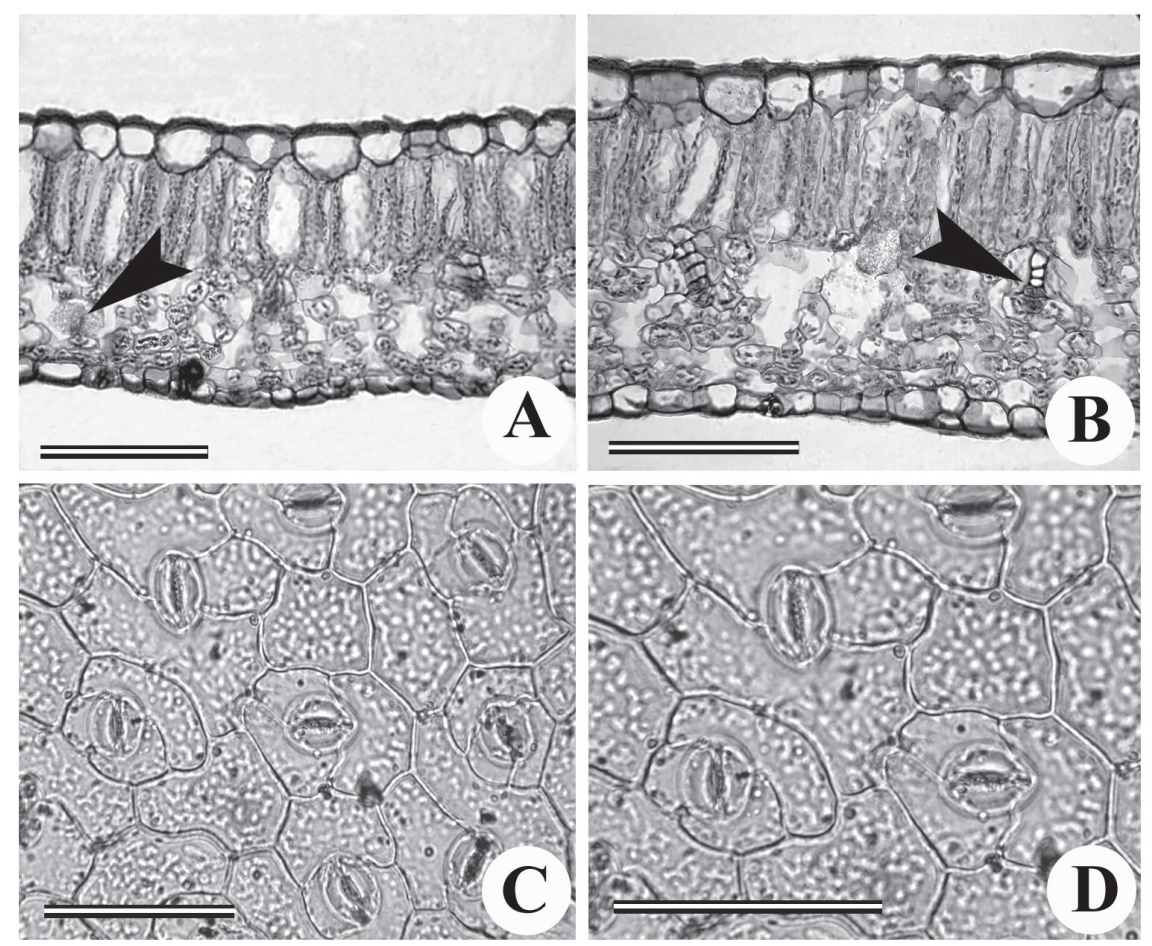

Figure 1. Transverse (A and B) view and leaf epidermal peel (C and D) of Solanum pseudocapsicum L., Solanaceae. A: Dorsiventral mesophyll in transection showing calcium oxalate needles in spongy cells (arrowhead). Note thick cuticle on the upper epidermis. B: Enlarged view of leaf transection showing arrangement of mesophyll cells and minor collateral vascular bundle (arrowhead). C: Face view of adaxial epidermis showing anomocytic stomata. D: Enlarged face view of adaxial epidermis showing anomocytic stomata. Scale Bar: $75 \mu \mathrm{m}$. 
smooth thick cuticle (Figure 1A, B). Covering trichomes were not much numerous, uniseriate with 2-3 cells. Stomata were anomocytic (Figure 1C, D). The mesophyll reveals dorsiventral organisation, comprising one stratum of palisade parenchyma and about four layers of spongy parenchyma (Figure 1A, B), the latter occupying 50-60\% of the mesophyll. Minor collateral vascular bundles were embedded in the mesophyll and are enclosed by a sheath of large parenchyma cells. Deposition of calcium oxalate needles were also observed in spongy parenchyma cells.

In the young stems, the epidermis consists of single compact layer of isodiametric and thin walled parenchyma cells. A thin layer of cuticle covers the epidermis while 2-3 layered hypodermis composed of parenchyma cells differentiated beneath it. The bulk of cortex consisted parenchyma cells that showed heavy accumulation of oval to circular, compound starch grains (Figure 2B, C). As the secondary growth progressed further in the mature stems, medullary phloem rays away from the cambium underwent obliteration and became tangentially flattened (Figure 2D).

Secondary xylem was diffused porous with indistinct growth rings and was composed of fibres, vessels, axial and ray parenchyma cells (Figure 2D). Vessels were mostly angular and possessed alternate bordered pits on their lateral walls. Perforation plates were simple and were arranged slightly oblique to transverse on the end walls. Vessel elements were 300 to $313 \mu \mathrm{m}$ in length and 48 to $73 \mu \mathrm{m}$ in diameter whereas xylem fibres were 550 to $623 \mu \mathrm{m}$ in length and possessed simple slit like pits. However, differentiation of vessels remained restricted to certain portion of the cambium while rest

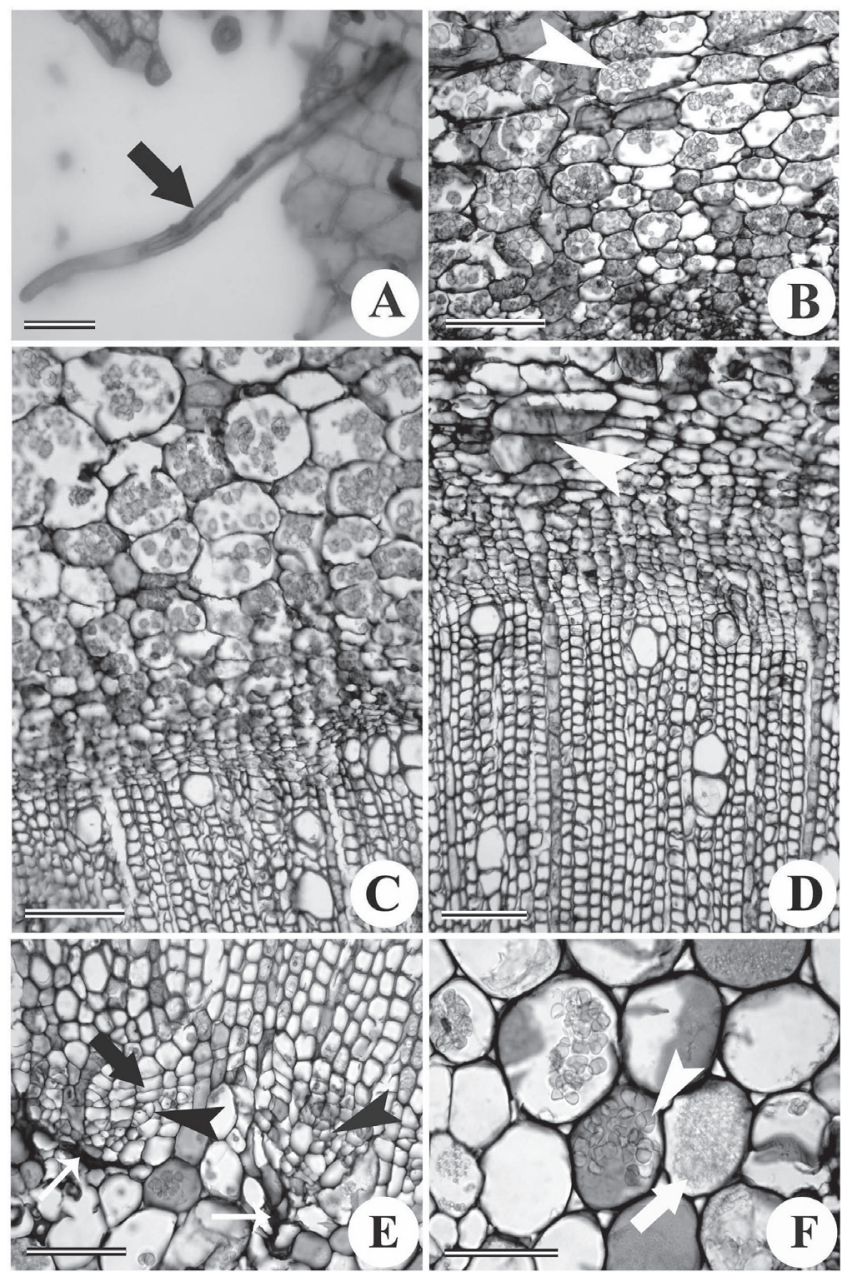

Figure 2. Leaf epidermal peel (A) and transverse (B-F) view of main stem of Solanum pseudocapsicum L. Solanaceae. A: Leaf peel showing warty trichome (arrow). B: Cortical parenchyma in mature stem with starch grains (arrowhead) note the tangentially flattened parenchyma on upper side while lower side shows phloem parenchyma. C: Young stem showing cortical parenchyma filled with starch grains (arrowhead). Note the larger circular cortical parenchyma cells as well as small phloem parenchyma showing starch deposition. D: Structure of xylem showing vessel differentiation is restricted only to the certain cambial cells. E: Marginal pith cells differentiated into internal cambium (arrow) note the secondary internal phloem (arrowhead) formed by the internal cambium. Small arrow showing obliterated internal protophloem. F: Enlarged view of pith cells with starch grains (arrowhead). Note the shape of the starch grains. Arrow indicates calcium oxalate needles in one of the pith parenchyma. Scale Bar: $100 \mu \mathrm{m}$. 
of the cambial cells exclusively differentiated into xylem fibres and axial parenchyma cells (Figure 2D).

External and internal morphology studies on any plant used in the Ayurvedic medicine are extremely important for the identification. Although, some sophisticated chemical and molecular methods are available for the identification of plant material, morphoanatomical methods are the simplest among the qualitative methods to avoid the falsification and adulteration of the drug (Sharma et al., 2010). Family Solanaceae is characterised by the presence of intraxylery phloem (Metcalfe \& Chalk, 1950, 1983). S. pseudocapsicum also showed presence of intraxylery phloem (Figure 2E). As the secondary growth progressed further, in mature stems the marginal pith cells acquired meristematic character and differentiate into internal cambium (Figure 2E). Vesque (1875) discovered such a cambium for the first time in the Solanaceae, the Asclepiadaceae and the Apocynaceae. Although intraxylary phloem is reported in several other families but there are very few species that develop internal cambium at the margin of pith. This internal cambium was functionally unidirectional and differentiated only into phloem elements in centripetal direction. Development of intraxylary secondary phloem exerted a pressure on the internal protophloem thus leading to obliteration and crushing of internal protophloem (Figure 2E). Pith cells were characterised by the presence of oval to circular and compound starch grains (Figure 2F) and calcium oxalate needles.

Both, in the stems as well as in roots, the xylem rays were mostly uni-biseriate with vertically elongated upright ray cells (Figure 3A, B). In the stem, deposition of starch was observed in the xylem fibres and ray parenchyma cells (Figure 3A, B). In roots, its deposition was restricted only to the axial and ray parenchyma cells while fibres were free from the starch (Figure 3C, D).

\section{Conclusion}

As a characteristic feature of the family, Solanum pseudocapsicum L., Solanaceae, also shows presence of primary and secondary intraxylary phloem. In the maturing stems, the marginal pith cells formed intraxylery phloem but in mature plants, internal cambium was developed from them that gave rise to secondary phloem centripetally.

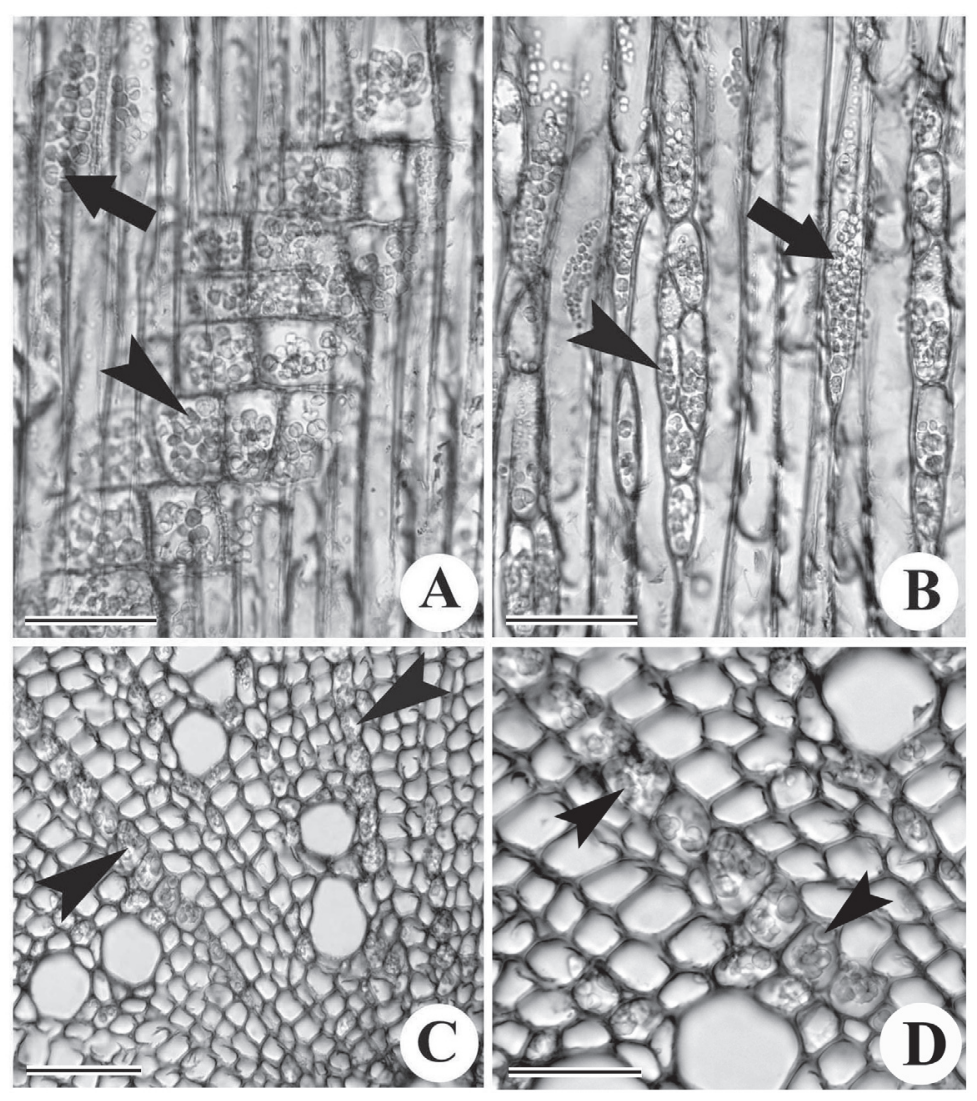

Figure 3. Radial (A), tangential (B) and transverse (C, D) view of xylem of Solanum pseudocapsicum L., Solanaceae. A: Xylem fibres (arrow) and ray parenchyma (arrowhead) of stem showing distribution of starch in the xylem. B: Uni-biseriate rays in the stem showing starch (arrowhead). Note the lumen of the xylem fibres showing deposition of starch (arrow). C: Distribution of starch remains restricted to the ray parenchyma cells in the roots arrowheads. D: Enlarged view of Figure 3C showing distribution of starch in the ray parenchyma cells of the roots. Scale Bar: $100 \mu \mathrm{m}$. 


\section{Acknowledgement}

The authors are thankful to the Department of Biotechnology, Ministry of Science and Technology, Government of India for the financial support. Thanks are also due to anonymous reviewers for their valuable suggestions on the manuscript.

\section{References}

Batten A, Bokelmann H 1966. Wild flowers of the Eastern Cape province. Cape and Transvaal Printers Ltd. Cape Town, p 129.

Bassett IJ, Mundro DB 1985. The biology of Canadian weeds: Solanum ptycanthum Dun, S. nigrum L. and $S$. sarrachoides Sendt. Can J Plant Sci 65: 401-414.

Berlyn GP, Miksche JP 1976. Botanical microtechnique and cytochemistry. The Iowa State University Press, Ames, Iowa, p.326.

Boericke W 1927. Pocket Manual of Homeopathic Materia Medica (9th ed.). Boericke and Runyon, New York, p. 598.

Dayang FB, Razinah S, Paden M 2005. Antimicrobial activities of ethanol and ethyl acetate extracts from the fruits of Solanum torvum. Appl Biol (Malays) 34: 31-36.

Gislene GF, Nascimento JL, Paulo CF, Guliana LS 2000. Antibacterial activity of plant extracts and phytochemicals on antibiotic resistant bacteria. Braz $J$ Microbiol 31: 247-256.

Johansen DA 1940. Plant Microtechnique. Mcgraw hill, New York.

Marchese A, Shito GC 2001. Resistance patterns of lower respiratory tract pathogens. in Europe. Int J Antimicrob Agents 16: 25-29.

Metcalfe CR, Chalk L 1950. Anatomy of the dicotyledons. Clarendon Press, Oxford.

Metcalfe CR, Chalk L 1983. Anatomy of dicotyledons. Vol IInd. Clarendon Press, Oxford.

Parisi P, Francia A 2000. A female with central anticholinergic syndrome responsive to neostigmine. Pediatr Neurol 23: 118-185.

Poole K 2001. Overcoming antimicrobial resistance by targeting resistance mechnisms. J Pharm Pharmacol 53: 283-84.

Rajput KS, Raole VM 2009. Solanum pseudo-capsicum L.: Addition to the Flora of Gujarat State. The Indian Forester 135: 1293-1295.

Sharma S, Hullatti KK, Prasanna SM, Sharma P 2010. Comparative morpho-anatomical and preliminary phytochemical studies of Cusucuta reflexa and Cassytha filiformis. Int. J Pharm Pharmaceut Sci 2 (Suppl 1): 5964.

Shrishailappa B, Reddy S, Kumar EP, Vijayan P, Suresh B 2003. Anti-tumour activity of total alkaloid fraction of Solanum pseudocapsicum. Phytotherapy 17: 10011004.
Vijayan P, Prashanth HC, Preethi V, Dhanaraj SA, Badami S, Suresh B 2003. Hepatoprotective effect of the total alkaloid fraction of Solanum pseudocapsicum leaves. Pharm Biol 41: 443-48.

Vesque J 1875. Mémoire sur l'anatomie comparée de l'écorce. Ann Sci Nat Bot 2: 82-198.

\section{*Correspondence}

Kishore S. Rajput

Department of Botany, Faculty of Science, The Maharaja Sayajirao University of Baroda, Vadodara 390 002, India ksrajput-botany@msubaroda.ac.in

Tel. +912652791891,+919428165791 